\title{
Eubacterium plautii (Séguin 1928) comb. nov.
}

\author{
TOR HOFSTAD AND PER AASJORD \\ The Gade Institute, Department of Microbiology and Immunology, University of Bergen, Bergen, Norway
}

\begin{abstract}
The type strain $($ ATCC $29863=$ VPI 0310) of Fusobacterium plautii has a multilayered cell envelope structure consisting of a barely visible cell membrane, a dense intermediate layer, and a single-layered outer membrane. The cells do not have flagella and are not motile in hanging drop preparations. The results of this and earlier investigations indicate that despite having a negative Gram reaction, this strain is a gram-positive bacterium with a gram-variable cell wall structure. Since the type strain of $F$. plautii fits the generic description of Eubacterium, the species is transferred to this genus as Eubacterium plautii (Séguin) comb. nov.
\end{abstract}

In 1907, Plaut (17) published a morphological description of motile fusiform bacteria that were isolated from ulceromembranous stomatitis in humans. He described the following two main forms: large fusiform rods with barely visible appendages all over the cell surface and a group of smaller, curved rods with a few, clearly visible flagella attached to either the ends or the concave sides of the cells. The second form was morphologically identical to "Spirillum sputigenum" described earlier by Miller (14) (names in quotation marks are not on the Approved Lists of Bacterial Names [20], have not been validly published since 1 January 1980 , and therefore have no standing in nomenclature). The name Fusobacterium plauti (sic) was introduced by Séguin (19), who succeeded in isolating the motile fusiform organism in pure culture. In smears from the cultures Séguin recognized the different morphological forms described by Plaut and concluded that the large motile organism and " $S$. sputigenum" of Miller represented different forms of the same anaerobic vibrio. The description of Fusobacterium plauti (sic) Séguin in Bergey's Manual of Determinative Bacteriology, 8th ed., is based mainly on the four known strains (VPI 0310, VPI 0311, VPI 0312, and VPI 4145) isolated by Prévot from cultures of Entamoeba histolytica (15).

During a study of the fatty acids of different fusobacteria, we found that the patterns of the Fusobacterium plautii strains differed markedly from those of the strains of other Fusobacterium species (11). 3-Hydroxy fatty acids, which are invariably present in gram-negative bacteria as constituents of cell wall lipopolysaccharides, were absent. Furthermore, water-soluble lipopolysaccharides were not extracted from the cells with $45 \%$ aqueous phenol (7). The results of these studies indicated that despite having a negative Gram reaction, the cells might have a cell wall structure of the type ordinarily associated with gram-positive bacteria. Therefore, cells of strain VPI 0310 were examined with an electron microscope and compared with cells of a strain of Fusobacterium nucleatum, which has a cell wall structure typical of gram-negative cells $(2,22)$. Also, by using light microscopy, we examined Gram-stained smears of strain VPI 0310 cultured for different periods of time and unstained preparations of living cells.

\section{MATERIALS AND METHODS}

Microorganisms. F. plautii strain VPI 0310 (= ATCC 29863 = Prévot S1) was obtained from the Anaerobe Laboratory, Virginia Polytechnic Institute and State University, Blacksburg. $F$. nucleatum strain Fev1 was supplied by S. E. Mergenhagen, National Institute of Dental Research, Bethesda, Md.

Cultural conditions. Cells were cultivated at $37^{\circ} \mathrm{C}$ in narrow-necked, screw-capped bottles filled to the top with medium containing the following (in grams per liter): tryptone (Oxoid Ltd., London, England), 15.0; $\mathrm{NaCl}, 5.0 ; \quad \mathrm{KH}_{2} \mathrm{PO}_{4}, 1.5 ; \mathrm{Na}_{2} \mathrm{HPO}_{4} \cdot 2 \mathrm{H}_{2} \mathrm{O}, 3.5$; $\mathrm{NaHCO}_{3}, 0.5$; yeast extract (Oxoid), 3.0; L-cysteine hydrochloride, 1.0; vitamin $\mathrm{B}_{12}, 0.001$; hemin, 0.005 ; menadione, 0.001 ; and glucose, 2.5. The $\mathrm{pH}$ of the medium was 7.0. Cells in the exponential or stationary phase of growth were harvested by centrifugation, washed once in phosphate-buffered saline ( $\mathrm{pH}$ 7.2), and prepared for electron microscopy as described below.

For the study of cell morphology in unstained preparations and in Gram-stained smears, cells of strain VPI 0310 were cultivated in a modified peptone yeast extract glucose medium (8) containing tryptone instead of peptone, $0.08 \%$ agar, and ascorbic acid as a reducing agent. Narrow tubes filled with the semifluid medium were inoculated with cells from an exponentially growing culture and incubated for $3,6,12$, or 24 h or for 2,6 , or 10 days.

Electron microscopy. Electron microscopy was carried out essentially as described by Kellenberger et al. (12); $3 \%$ glutaraldehyde in $0.2 \mathrm{M}$ cacodylate buffer ( $\mathrm{pH}$ 
7.4) (18) was used as the fixative, and Spurr medium (21) was used for embedding. Embedded preparations were cut into thin sections (40 to $60 \mathrm{~nm}$ ) with an ultramicrotome (LKB Produkter, Uppsala, Sweden), and the thin sections were transferred to grids (150) mesh). The grids were treated with $2 \%$ aqueous uranyl acetate for $30 \mathrm{~min}$, thoroughly rinsed in water, treated with Reynolds lead citrate for $15 \mathrm{~min}$, and finally washed in water.

Negative staining was performed with $2 \%$ aqueous phosphotungstic acid adjusted to $\mathrm{pH} 6.6$.

All electron microscopic observations were made with a Hitachi model $\mathrm{HU} 12 \mathrm{~A}$ electron microscope at $100 \mathrm{kV}$.

Gram staining. Gram staining was performed as outlined in the Manual of Clinical Microbiology (13); Gram crystal violet (Difco Laboratories, Detroit, Mich.) and ethyl alcohol (as decolorizer) were used.

Examination for motility. Hanging drop preparations of cells in the exponential phase of growth were examined by phase-contrast microscopy.

\section{RESULTS}

In Gram-stained smears, cells of $F$. plautii VPI 0310 appeared as straight or slightly curved rods 5 to $10 \mu \mathrm{m}$ long with rounded ends. Some cells were fusiform. Cells grown for $48 \mathrm{~h}$ or less were uniformly gram negative. Gram-positive cells or gram-negative cells containing grampositive granules were not observed. In addition, older cultures contained cells with bulbous swellings or vacuoles, as well as a few filaments. Structures resembling endospores were not observed. In unstained preparations the cells were nonmotile.

Cells of strain VPI 0310 appeared in thin sections as elongated structures whose shorter diameter ranged from 480 to $680 \mathrm{~nm}$. In a few cells a membranous structure, interpreted as the plasma membrane, was partly discernible in close contact with the cytoplasm (Fig. 1a through $\mathrm{c}$ ). The multilayered cell wall was approximately $50 \mathrm{~nm}$ wide. The dominating structure was a densely stained layer $5 \mathrm{~nm}$ wide in close contact with the plasma membrane or separated from it by an unstained or lightly stained space. This layer was present in cross walls between adjacent cells (Fig. 1a and b); most likely it represents peptidoglycan. All cells contained a thick outer layer (approximately 20 $\mathrm{nm}$ wide) that was slightly separated from the densely stained structure or in close contact with it. This layer followed a straight-line course and was quite distinct from the wavy, triplelayered outer membrane of $F$. nucleatum Fev1 (Fig. 1d). Also, the $F$. nucleatum cells had a clearly visible triple-layered plasma membrane.

The cytoplasm of both $F$, plautii and $F$. nucleatum consisted of a granular, electron-dense material, whereas the nuclear regions displayed a less dense, filamentous structure (Fig. 1b).
Membranous structures suggestive of mesosomes were not observed. Peculiar unstained rod-shaped areas were observed in some cells (Fig. 1a). Flagella were not observed in negatively stained preparations.

\section{DISCUSSION}

In thin sections, $F$. plautii VPI 0310 displayed a cell wall profile distinct from that of $F$. nucleatum Fev1, which showed a cell wall profile typical of gram-negative bacteria (3). Also, the cell wall of VPI 0310 differed from the rather thick and homogeneous wall of a typical grampositive bacterium (4). Cell boundary layers more or less similar to those of $F$. plautii VPI 0310 have been observed in the sporeformers Bacillus polymyxa (16) and Bacillus sphaericus (10), in the nonsporeforming anaerobe Eubacterium saburreum (6), and in Gardnerella vaginalis $(1,5)$. These organisms have in common the ready loss of Gram positivity in aging cultures.

The lipopolysaccharide-lipoprotein complex of a gram-negative bacterium is associated with the outer, triple-layered membrane. The complete lack of such a membrane in $F$. plautii VPI 0310 explains why lipopolysaccharide could not be obtained from whole cells by extraction with $45 \%$ aqueous phenol (7) and why hydroxy fatty acids were absent in cell methanolysates (11).

The results of this study and of earlier investigations $(7,11)$ suggest that the strains of $F$. plautii are representatives of an anaerobic, nonmotile, nonsporeforming, gram-positve bacterium. This bacterium is certainly not identical to the oral organism (or organisms) described by Plaut (17) and Séguin (19). The drawings of Séguin (19) of vibrios and long bacterial cells with several curves are suggestive of a spirillum. We have observed similar morphological forms in Gram-stained smears from cultures of an oral strain of Selenomonas.

Two important taxonomic considerations have emerged from our studies. First, despite having a negative Gram reaction, $F$. plautii is a nonmotile, gram-positive organism. And second, the placement of this organism in the genus Fusobacterium is in error; the biochemical properties of the known strains of $F$. plautii (15), including the type strain, particularly the production in peptone yeast extract glucose broth of butyric acid as a major product together with smaller amounts of acetic, lactic, and succinic acids, fit the generic description of Eubacterium (9), but they are not fully compatible with the description of any of the Eubacterium species listed in Bergey's Manual, 8th ed. Therefore, we suggest a transfer of this species to the genus Eubacterium, as Eubacterium plautii (Séguin) comb. nov. 

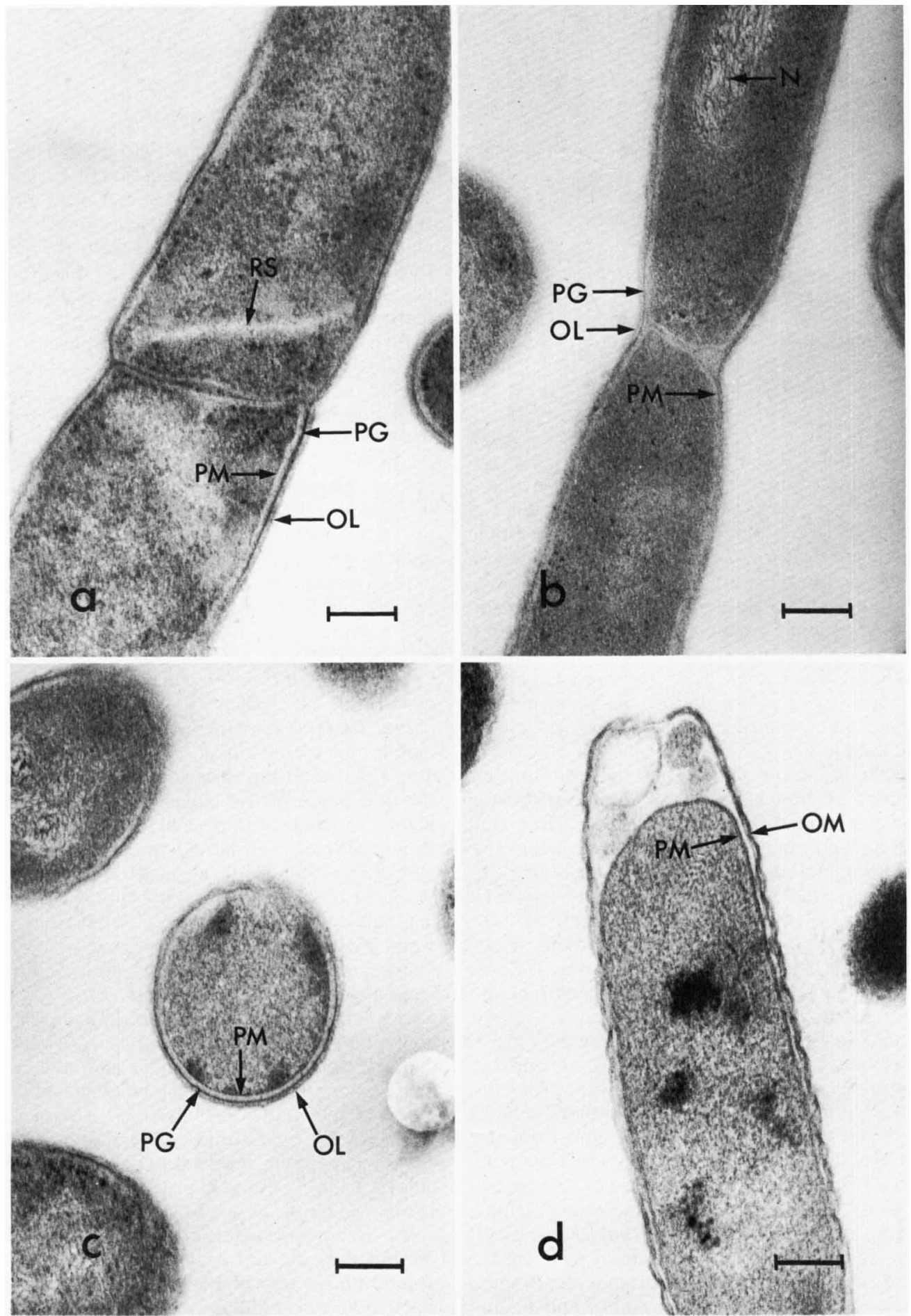

FIG. 1. Electron micrographs of ultrathin sections of strain VPI 0310 (a through $\mathrm{c}$ ) and $F$. nucleatum strain Fev1 (d). PM, Plasma membrane; OM, outer membrane; OL, outer layer; PG, peptidoglycan; RS, rod-shaped structure; N, nuclear region. Bars $=200 \mathrm{~nm}$. 


\section{ACKNOWLEDGMENTS}

We are most grateful to W. E. C. Moore and L. V. Holdeman, who supplied a culture of $F$, plautii strain VPI 0310 and cultural and biochemical data from their investigations.

This study was supported by the Norwegian Research Council for Science and the Humanities.

\section{REPRINT REQUESTS}

Address reprint requests to: Dr. Tor Hofstad, Avd. for mikrobiologi og immunologi, MFH-bygget, N-5016 Haukeland sykehus, Norway.

\section{LITERATURE CITED}

1. Criswell, B. S., J. H. Marston, W. A. Stenback, S. H. Black, and H. L. Gardner. 1971. Haemophilus vaginalis 594, a gram-negative organism? Can. J. Microbiol. $17: 865-869$

2. Dahlén, G., H. Nygren, and H.-A. Hansson, 1978. Immunoelectron microscopic localization of lipopolysaccharides in the cell wall of Bacteroides oralis and Fusobacterium nucleatum. Infect. Immun. 19:265-271.

3. de Petris, S. 1965. Ultrastructure of the cell wall of Escherichia coli. J. Ultrastruct. Res. 12:247-262.

4. Glauert, A. M., and M. J. Thornley. 1969. The topography of the bacterial cell wall. Annu. Rev. Microbiol. 23:159-198.

5. Greenwood, J. R., and M. J. Pickett. 1980. Transfer of Haemophilus vaginalis Gardner and Dukes to a new genus, Gardnerella: G. vaginalis (Gardner and Dukes) comb. nov. Int. J. Syst. Bacteriol. 30:170-178.

6. Hofstad, T., and K. A. Selvig. 1969. Ultrastructure of an anaerobic filamentous oral micro-organism. J. Gen. Microbiol. 57:221-225.

7. Hofstad, T., and N. Skaug. 1980. Fatty acids and neutral sugars present in lipopolysaccharides isolated from Fusobacterium species. Acta Pathol. Microbiol. Scand. Sect. B 88:115-120.

8. Holdeman, L. V., E. P. Cato, and W. E. C. Moore (ed.). 1977. Anaerobe laboratory manual, 4th ed. Anaerobe Laboratory, Virginia Polytechnic Institute and State University, Blacksburg.

9. Holdeman, L. V., and W. E. C. Moore. 1974. Eubacterium Prévot 1938, p. 641-657. In R. E. Buchanan and N. E.
Gibbons (ed.), Bergey's manual of determinative bacteriology, 8th ed. The Williams \& Wilkins Co., Baltimore.

10. Holt, S. C., J. J. Gauthier, and D. J. Tipper. 1975. Ultrastructural studies of sporulation in Bacillus sphaericus. J. Bacteriol. 122:1322-1338.

11. Jantzen, E., and T. Hofstad. 1981. Fatty acids of Fusobacterium species: taxonomic implications. J. Gen. Microbiol. 123:163-171.

12. Kellenberger, E., A. Ryter, and J. Sechaud. 1958. Electron microscopic study of DNA-containing plasms. II. Vegetative and mature phage DNA as compared with normal bacterial nucleoids in different physiological states. J. Biophys. Biochem. Cytol. 4:671-678.

13. Lennette, E. H., A. Balows, W. J. Hausler, Jr., and J. P. Truant (ed.). 1980. Manual of clinical microbiology, 3rd ed. American Society for Microbiology, Washington, D.C.

14. Miller, W. D. 1889. Die Mikroorganismen der Mundhöhle. Die örtlichen und allgemeinen Erkrankungen welche durch dieselben hervorgerufen werden. Georg Thieme Verlag, Leipzig.

15. Moore, W. E. C., and L. V. Holdeman. 1974. Fusobacterium Knorr 1922, p. 404-416. In R. E. Buchanan and N. E. Gibbons (ed.), Bergey's manual of determinative bacteriology, 8th ed. The Williams \& Wilkins Co., Baltimore.

16. Nermut, M. V., and R. G. E. Murray. 1967. Ultrastructure of the cell wall of Bacillus polymyxa. J. Bacteriol. 93:1949-1965.

17. Plaut, H. C. 1907. Über die Geisseln bei fusiformen Bacillen. Zentralbl. Bakteriol. Parasitenkd. Infektionskr. Abt. 1 Orig. 44:310-316.

18. Sabatini, D. D., K. Bensch, and R. J. Barrnett. 1963. Cytochemistry and electron microscopy. The preservation of cellular ultrastructure and enzymatic activity by aldehyde fixation. J. Cell Biol. 17:19-58.

19. Séguin, P. 1928. Culture du Fusobacterium plauti, forme mobile du Bacille fusiforme. C. R. Soc. Biol. 99:439-442.

20. Skerman, V. B. D., V. McGowan, and P. H. A. Sneath (ed.). 1980. Approved lists of bacterial names. Int. J. Syst. Bacteriol. 30:225-420.

21. Spurr, A. R. 1969. A low-viscosity epoxy resin embedding medium for electron microscopy. J. Ultrastruct. Res. 26:31-43.

22. Takagi, A., and K. Ueyama. 1963. Characteristic cell wall structure of a Fusobacterium. Jpn. J. Microbiol. 7:43-51. 